\title{
Molecular Systematics of the Endangered O'ahu Tree Snail Achatinella mustelina: Synonymization of Subspecies and Estimation of Gene Flow between Chiral Morphs ${ }^{1}$
}

\author{
Brenden S. Holland ${ }^{2,3}$ and Michael G. Hadfield ${ }^{4}$
}

\begin{abstract}
The single-island endemic $\mathrm{O}^{\prime}$ ahu tree snail Achatinella mustelina Mighels, 1845 is an endangered species with dimorphic shell chirality, persisting in small populations restricted to upper-elevation native forest in the Wai'anae Mountains. We used an intraspecific molecular phylogeny ( $n=21$ populations) to evaluate the validity of subspecies, most of them introduced by Welch in 1938 on the basis of shell characters, by determining whether the nominal subspecies examined correspond to detectable molecular partitions and to examine the possibility that opposing shell chirality acts as a reproductive isolating mechanism. We mapped the nominal subspecies and shell chiralities onto a mitochondrial DNA (mtDNA) phylogram based on 86 cytochrome $c$ oxidase I gene fragments and the extant range of the species. Although clear genetic breaks and haplotype clusters with well-defined boundaries exist and correspond to topographic features, each of the five monophyletic clades in the gene tree contains multiple supposed subspecies, haplotypes are shared between different subspecies, and none of the 13 nominal subspecies exhibits monophyly. Furthermore the mtDNA clades in the gene tree do not correspond to observed patterns in shell chirality, and both chiralities occur in all clades. Thus, the subspecies are not taxonomically valid and have no relevance for conserving genetic diversity, and chirality differences do not appear to impart a reproductive barrier in this species. Therefore, all subspecies of $A$. mustelina are herein synonymized.
\end{abstract}

${ }^{1}$ This research was supported by grants to M.G.H. from the U.S. Fish and Wildlife Service and the U.S. Army. Manuscript accepted 14 March 2006. .edu).

${ }^{2}$ Corresponding author (e-mail: bholland@hawaii

${ }^{3}$ Center for Conservation Research and Training, Pacific Biosciences Research Center, 3050 Maile Way, University of Hawai'i at Mānoa, Honolulu, Hawai'i 96822.

${ }^{4}$ Kewalo Marine Laboratory, Pacific Biosciences Research Center, University of Hawai'i, 41 'Āhui Street, Honolulu, Hawai'i 96813 and Department of Zoology, University of Hawai'i at Mānoa, Honolulu, Hawai'i 96822.

Pacific Science (2007), vol. 61, no. 1:53-66

(C) 2007 by University of Hawai'i Press

All rights reserved
(The) extraordinary Hawaiian biota would have continued its remarkable adaptive radiation at a rapid rate had man not caused its recent decimation.

—E. C. Zimmerman (1979:38)

HaWAi'i's BIOLOGICAL RADIATIONS provide superb models for the study of evolution, speciation, and biogeography (e.g., Carson and Kaneshiro 1976, Simon 1987, Wagner and Funk 1995, Parsons and Shaw 2001, Gillespie and Roderick 2002, Price and Clague 2002, Jordan et al. 2003). Although many Hawaiian terrestrial plant and animal assemblages have received recent genetic scrutiny, molecular studies focusing on endemic Hawaiian land snail biogeography and radiations remain relatively few (Thacker and Hadfield 2000, Holland and Hadfield 2002, 2004, Rundell et al. 2004). With 99 single-island endemic, nomenclaturally valid species in four genera (Cowie et al. 1995) and a maximum lineage age of 3.7 myr (Holland and Hadfield 
2004), the tree snails in the subfamily Achatinellinae represent one of the more spectacular examples of recent Hawaiian radiations. Lacking adaptive radiation patterns seen in a number of insect, bird, and plant lineages that are characterized by high morphological and ecological diversity, the achatinelline radiation is atypical in that all members of the subfamily share generally the same reproductive strategy, feeding mode, and gross morphology.

The rich coloration and highly varied banding patterns of achatinelline snail shells captured the attention of early naturalists and shell collectors, many of whom collected and killed thousands of specimens during the late 1800s and early 1900s (Hadfield 1986, Hadfield et al. 1993). The Hawaiian tree snails are historically important for their role in promoting general awareness of the unique Hawaiian flora and fauna, as well as inspiring early evolutionary theory aimed at understanding diversification patterns and mechanisms (Gulick 1905).

In recent years the Hawaiian tree snails have increasingly gained attention because of their grim conservation status. Extinction rates for Hawaiian land snails in general have been estimated as 65-90\% (Solem 1990, Cowie 2001) and for tree snails in particular as 75\% (M.G.H. and B.S.H., unpubl. data). Range reductions for the tree snails have surpassed 90\% (U.S. Fish and Wildlife Service 1993). Since 1981, the endemic O'ahu genus Achatinella has been listed as endangered under the U.S. Endangered Species Act (U.S. Fish and Wildlife Service 1981), and although the other genera and species from neighboring high islands are critically threatened, they are currently not federally listed. Predation by rats and the snail Euglandina rosea (Hadfield 1986, Hadfield et al. 1993, Cowie 2001) has had devastating impacts and threatens to eliminate all extant taxa. Today, it is likely that there are only 10 or 11 species of Achatinella extant in the wild (B.S.H., pers. obs.), most of which persist in small, isolated populations.

\section{O'abu Tree Snail Nomenclature}

O'ahu tree snails are arboreal snails with shells $12-30 \mathrm{~mm}$ in height, usually ovate/ conical, and often brightly colored and beautifully patterned. Although some species now placed in Achatinella were described in other genera, including Helix Linnaeus, 1758, Turbo Linnaeus, 1758, Achatina Lamarck, 1799, and Monodonta Lamarck, 1799, most were placed in these genera before Swainson's introduction of Acbatinella or very shortly thereafter, before Achatinella was well recognized. During the nineteenth century many species now assigned to other genera of the subfamily Achatinellinae (Partulina Pfeiffer, 1854, Newcombia Pfeiffer, 1854, and Perdicella Pease, 1869) were described as species of Achatinella, as were a number of species now assigned to the family Amastridae. As currently defined, Achatinella has the limits set for it by Pilsbry and Cooke (1912-1914), but morphological differences used to distinguish Partulina from Achatinella are not always clear in practice, and their separation at the generic level has been disputed in two molecular studies (Thacker and Hadfield 2000, Holland and Hadfield 2004).

The extreme diversity of color pattern exhibited by Achatinella species led nineteenthcentury systematists to describe a multitude of "species," many of which were later synonymized. In their systematic revision of the genus Achatinella, Pilsbry and Cooke (19121914) noted that more than 170 species-level names were available, that Baldwin (1893) had recognized 106 species, and Sykes (1900) had reduced this to 72 . Several taxonomic efforts to split the 41 nominal species of Achatinella recognized by Pilsbry and Cooke (1912-1914) into additional taxa were made by Welch $(1938,1942,1954,1958)$, including his review of $A$. mustelina Mighels, 1845, which introduced 21 new subspecies (Welch 1938). In total, a staggering 314 names (including 45 that are nomenclaturally unavailable) have been used for taxa in the genus Achatinella (Cowie et al. 1995).

We used the maps and subspecies descriptions of Welch (1938) to place multiple individuals of his subspecies on a cytochrome $c$ oxidase I (COI) gene tree, modified from Holland and Hadfield (2002). Between 1931 and 1936, Welch and his assistants collected 15,176 specimens from 582 localities in the 


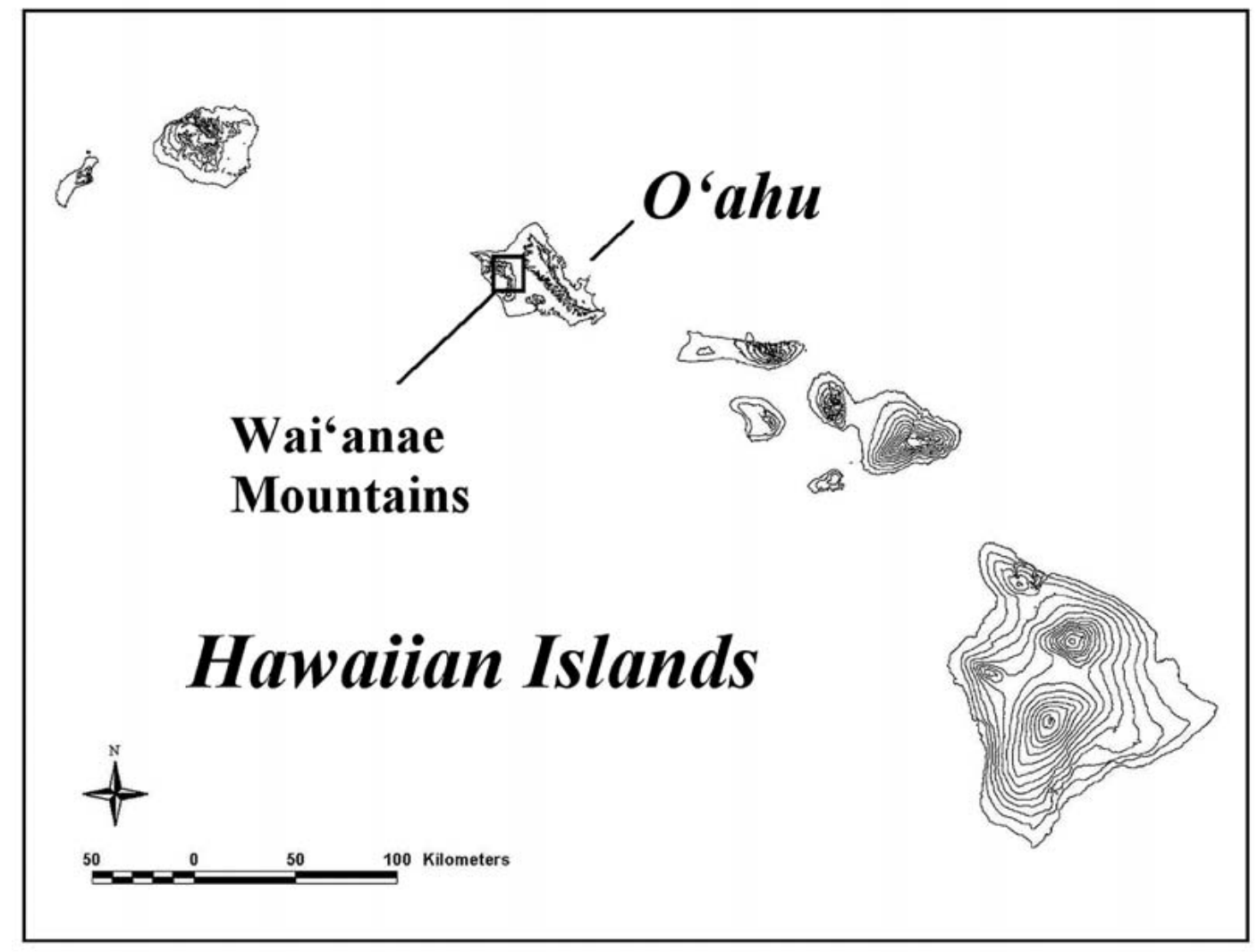

FIGURE 1. Map of the high islands of Hawai'i, highlighting the island of $\mathrm{O}^{\prime}$ ahu. Also labeled is the approximate position of the Wai'anae Mountains, running in a roughly northwest to southeast arc spanning about $24 \mathrm{~km}$.

Wai'anae Mountains (Figure 1) and examined tens of thousands of shells in the field. We sampled Achatinella mustelina corresponding to 13 of the 25 subspecies recognized by Welch (26 including A. m. mustelina). Although our sampling covers only half of these subspecies, it is likely that-because of habitat loss, range reduction, and population extinction-the samples obtained represent most if not all of the remaining populations of Welch's subspecies.

If the 13 Welch subspecies evaluated in this study were found to correspond to distinct molecular partitions, field biologists and resource managers would have a useful diagnostic field tool at their disposal for identification of natural diversity patterns in this species. The characters used by Welch in defining the complex patterns of variation in $A$. mustelina subspecies, "forms," or "races," as he alternately refers to them, include shell color, banding pattern, and shape. However, many of Welch's descriptions are difficult to follow, because although eloquent and highly detailed they are also subjective in terms of the nature of the language used and, in particular, color morph descriptions. For example, Welch described $A$. m. mustelina as follows: "The typical form and color pattern of the shell in area 6 measures, length 20.7 $\mathrm{mm}$., greater diameter $12.2 \mathrm{~mm}$., spire height $11.3 \mathrm{~mm}$., embryonic whorls white, postembryonic whorls white shading to pale smoke gray and on the last whorl, spirally banded on the last whorls with hair brown shading to buffy brown on the last whorl, sutural band white, subsutural band pale pinkish buff shading to pinkish buff on the last whorl, 
lip and columella callus cinnamon pink" (Welch 1938:26). In another entry, Welch described A. m. kapuensis: "The shell may be white banded just above the edge of the periphery and on the first postembryonic and penultimate whorls with a band of vinaceous fawn darkening to a dark vinaceous brown to seal brown, spirally lined with white, on the last whorl one band above the periphery of avellaneous, below the periphery a band 3.5 $\mathrm{mm}$. wide of deep plumbago gray lined with white fading out on the last half whorl to pearl gray and three lines of black; the third or lower band neutral gray" (Welch 1938:139). At one point Welch remarked, "This race $(A . m$. mustelina) however, is so like A. m. brunicolor var. from Makaha and even color patterns from Ekahanui that it would be impossible to separate mixed lots completely" (Welch 1938:26). In fact, this type of comment, stating that when lots are mixed they are impossible to separate, is not unusual in the text, nor is it surprising given the sheer variety and chaotic distribution of shell sculpture, color, and banding patterns and the fact that many grade together along ridge crests. But the idea that subspecies descriptions lose their value when shells from different areas are mixed raises fundamental problems with the use of these shell characters in terms of their information content, repeatability, biological validity, and systematic utility.

Although Welch's subspecies designations are not currently in use in the primary scientific literature, they remain taxonomically valid (Cowie et al. 1995) because they have never been synonymized, and they continue to be used by field biologists in the gray literature including field notes, surveys, and reports.

One of the principal issues that we addressed is whether more genetic diversity is contained in subspecies groupings of Welch (1938) or via genetically defined evolutionary significant units (ESUs) (Holland and Hadfield 2002). If the subspecies are an accurate reflection of the evolutionary history of A. mustelina, the expectation would be that the extent of DNA divergence and other measures of population subdivision would in- dicate a close relationship among molecular sequences sampled from each subspecies. If population structure follows the patterns proposed by Welch, then the subspecies names could be useful in terms of conservation and management efforts for this species.

\section{Speciation and Gene Flow between Tree Snails of Opposite Chirality}

Snails coil to the right (dextral) or the left (sinistral). In hermaphroditic, cross-fertilizing pulmonate land snails, populations of a single species rarely exhibit bimodal chirality (dextral and sinistral shells) (Johnson et al. 1990). Among these pulmonates, chiral dimorphism is related to shell shape and reproductive behavior (Asami et al. 1998). Flat-shelled species tend to align "face to face" during courtship and copulation, which is reciprocal, but if the snails are of different chirality this precludes the necessary reciprocal penial insertion. Tall-spired species, however, tend to mate nonreciprocally, with one snail mounting the shell of the other ("shell-mounting"), which requires only minor behavioral adjustments for copulation between snails of different chirality to take place (Asami et al. 1998). Thus, interchiral mating might be expected to be more frequent in tall-shelled than in flat-shelled species, and tall-shelled species would be expected to exhibit chiral dimorphism more frequently than flat-shelled. By estimating interchiral versus intrachiral gene flow inferred from mitochondrial DNA (mtDNA) sequence analyses, we can determine whether gene flow is restricted between individuals with opposite chirality.

Achatinella mustelina is a relatively tallspired species, and its populations exhibit mixed shell chirality, as noted by Pilsbry and Cooke (1912-1914) and Welch (1938). The tendency in this species for oppositely coiled shells to occur in sympatry is interesting in light of the possibility that individuals of opposing chirality are reproductively isolated, suggesting a potential speciation mechanism (Crampton 1917, Davison et al. 2005). To evaluate the roles of reproductive isolation and gene flow in the chiral evolution and possible incipient speciation of $A$. mustelina, we 
focused on populations in which both chiral morphs coexist.

\section{MATERIALS AND METHODS}

\section{Sampling}

Tissue samples were collected from live, reproductively mature tree snails using the methods of Thacker and Hadfield (2000). A very small $(10-20 \mathrm{mg})$ piece of tissue was sliced from the posterior tip of the extended foot as the animal crawled on a flat surface, placed in $95 \%$ ethanol in the field, and transported to the laboratory for genomic DNA extraction. This method was first tested in the laboratory on nonendangered species, and $100 \%$ survival of sampled snails was demonstrated. Ingroup taxa included Achatinella mustelina from throughout its range in the Wai'anae Mountains on western $\mathrm{O}^{\circ}$ ahu (Figure 2).

\section{DNA Extraction, PCR Amplification, and Sequencing}

Mitochondrial DNA (mtDNA) COI fragments were amplified and sequenced from 86 specimens including three endangered Hawaiian tree-snail species (Achatinella sowerbyana, A. concavospira, A. mustelina) and one nonendangered achatinellid outgroup (Auriculella ambusta). The ingroup, Achatinella mustelina, was sampled from 21 localities, including three additional populations (Kalua'a Gulch, Mākaha, and Mohiākea) since the previously published data set of Holland and Hadfield (2002). Genomic DNAs were extracted following the manufacturer's protocol using QIAGEN DNeasy nucleic acid extraction kits (QIAGEN, Inc., Valencia, California). DNAs were eluted in deionized autoclaved water and stored at $-70^{\circ} \mathrm{C}$. Polymerase chain reaction (PCR) was performed using a PTC-100 thermocycler (MJ Research, Inc.). Universal COI primers (Folmer et al. 1994) were used to amplify the target fragment under the following PCR conditions: 2 min at $92^{\circ} \mathrm{C}, 35$ cycles of $94^{\circ} \mathrm{C}$ degrees for $30 \mathrm{sec}, 48^{\circ} \mathrm{C}$ for $30 \mathrm{sec}$, and $72^{\circ} \mathrm{C}$ for $45 \mathrm{sec}$, with a final $72^{\circ} \mathrm{C}$ extension for $7 \mathrm{~min}$.
PCR-amplified DNA fragments were purified with QIAquick spin columns (QIAGEN, Inc.), according to the manufacturer's protocol, then checked via agarose gel electrophoresis. Amplified DNA fragments were cycle-sequenced using PCR primers and ABI Prism DYE Terminator Cycle Sequencing Reaction Kits to generate single-stranded products. Sequences were determined using an ABI 377 automated sequencer (PE Biosystems, Foster City, California).

\section{Phylogenetic Approach}

PAUP* 4.0b10 (Swofford 2002) and Modeltest v3.06 (Posada and Crandall 1998) were used to select the optimal substitution model to produce phylogenetic trees and distance matrices. Statistical support was assessed with 1,000 bootstrap replicates (Felsenstein 1985). Maximum likelihood was employed with a user-defined substitution rate matrix, gamma shape parameter, and proportion of invariant sites based on the Modeltest results. Modeltest runs through PAUP* and determines likelihood scores for 56 progressively complex models of sequence evolution in a hierarchical fashion (Posada and Crandall 1998). This method then uses a likelihood ratio test and identifies the optimal model using a chisquare distribution. Tree topologies produced using different optimality criteria, including default parameters and settings, were nearly identical.

\section{Nucleotide Polymorphism}

We used several methods to compute comparative statistics for DNA sequences, to quantify and understand the distribution of polymorphism and to infer patterns of gene flow in A. mustelina. A coalescent estimation approach was employed using the program SITES (Hey and Wakeley 1997) to compare fixation indices $F_{\mathrm{ST}}$ (Wright 1978) among and within different population groupings. We also used DNAsp (Rozas et al. 2003) to estimate population-level parameters and their variances, including the coefficient of gene differentiation $G_{\mathrm{ST}}$ (Nei 1982), pairwise nucleotide diversity $\pi$, haplotype diversity $H_{\mathrm{d}}$, 


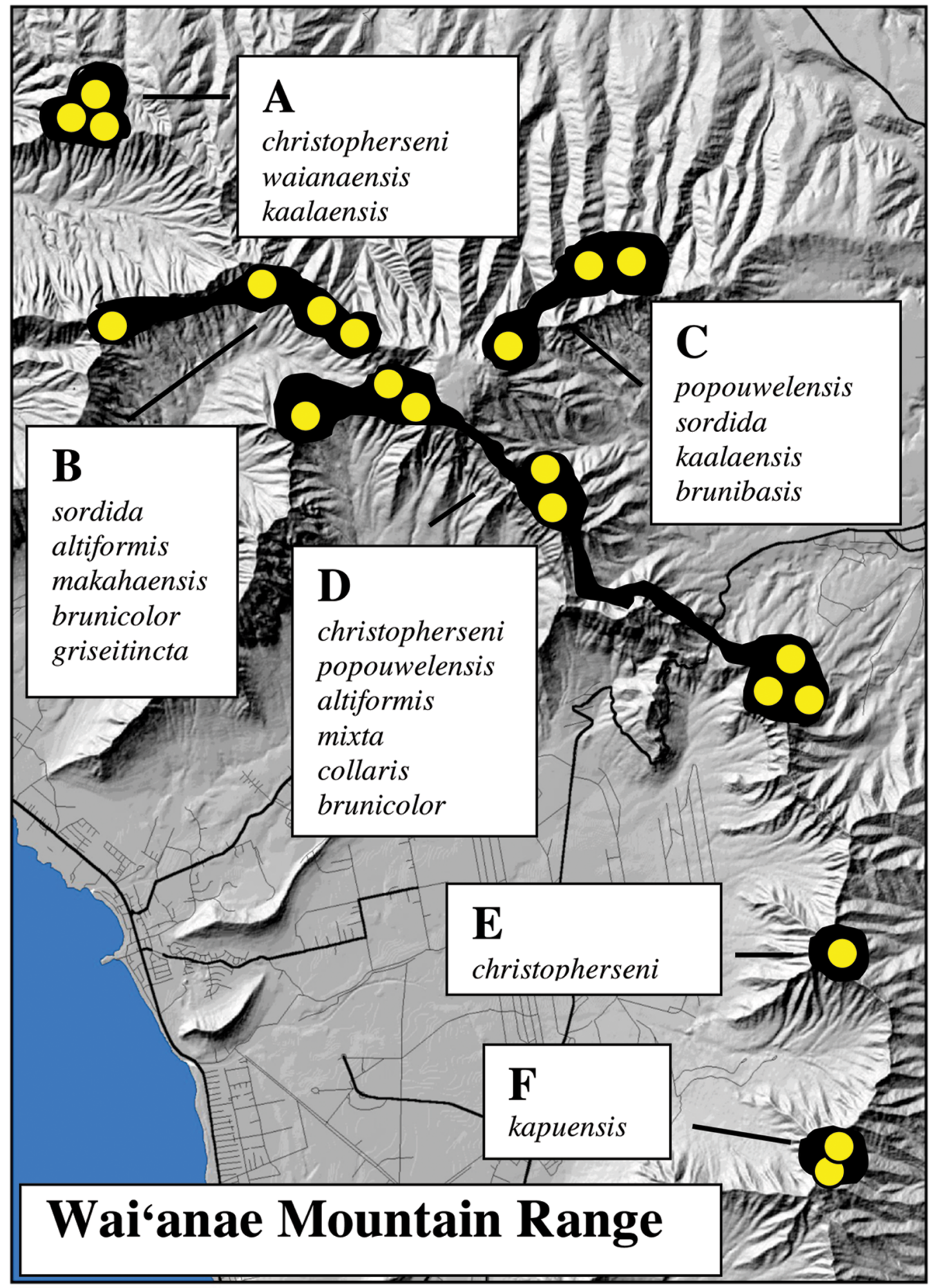

FIGURE 2. Map of the western region of the island of $\mathrm{O}^{\mathrm{s}} \mathrm{ahu}$, showing approximate sampling localities (circles) and clusters of closely related haplotypes or ESUs (blackened areas) for Achatinella mustelina, corresponding to monophyletic groups of populations sampled (adapted from Holland and Hadfield 2002). For each of the six main clades, the associated Welch (1938) subspecies names are shown in white boxes, along with labels A-F corresponding to labeled clades in Figure 3. 
mean number of haplotype substitutions per site between populations $D_{\mathrm{xy}}$, number of net nucleotide substitutions per site, and number of migrants $N_{\mathrm{m}}$ (Hudson et al. 1992).

RESULTS

\section{COI Sequence Polymorphism and Base Frequencies}

Sequence data were generated, aligned, and analyzed for 86 specimens representing four species. After alignment and editing, partial COI sequences consisted of 675 base pairs (bp) representing 225 codons. COI sequences were found to be A-T rich $(\mathrm{A}+\mathrm{T}=71.1 \%)$ and showed an average transition/transversion ratio (ti/tv) bias of approximately 3/1; third codon position substitutions were most common (84.1\%). Of $78 \mathrm{~A}$. mustelina sequences analyzed there were 54 unique haplotypes. Values of nucleotide diversity within putative subspecies were $\pi=0.0$ to 0.025 (mean 0.00766). Approximate geographic positions of sampling sites and of ESUs are shown in Figure 2.

\section{Phylogenetic Results}

Tree topologies based on COI gene fragments revealed deep phylogeographic structuring among clusters of populations (Figure $3)$. The overall phylogenetic pattern in $A$. mustelina was consistent regardless of the phylogenetic approach used (parsimony, minimum evolution, maximum likelihood). The tree topology reflects a pattern characterized by low intrapopulation divergence values and relatively high interpopulation divergence values (Holland and Hadfield 2002), and six main clades. This pattern suggests more recent historical genetic exchange among populations within the clades depicted, labeled A-F (Figure 3).

Comparative Genetic Partitioning: Among ESUs versus among Subspecies

The mean $G_{\mathrm{ST}}$ values were significantly lower within ESUs than within subspecies (Table 1), indicating that gene flow within ESUs is higher than within the nominal subspecies. $F_{\mathrm{ST}}$ values were far higher among ESUs than among sequences grouped by subspecies (Figure 4). Such comparisons again suggest higher gene flow within ESUs than among ESUs, within subspecies (Table 1) or among populations selected at random (Figure 4). Estimated gene flow (expressed as theoretical numbers of migrants) among ESUs was 4.36, and 26.13 between snails of different chirality. In addition we calculated Fu and Li's (1993) $\mathrm{F}^{*}$ and $\mathrm{D}^{*}$ statistics to test various predictions made by neutral evolutionary theory. These measures showed no indication of selection on the COI gene fragment.

\section{Evolution of Chirality in A. mustelina}

Among the snails in our data set $58 \%$ were sinistral and $42 \%$ dextral. Among the 20,056 specimens of the 13 subspecies included in our phylogeny that were examined and measured by Welch (1938), 42\% were sinistral and $58 \%$ dextral. Achatinella mustelina is a high-spired pulmonate, and, as predicted by Asami et al. (1998) for high-spired snails, interchiral mating should readily take place in this species. All of the subspecies of Welch (1938) included snails of both chiralities, although a minority of populations consisted of all dextral or all sinistral shells.

\section{SYSTEMATICS}

As a result of this molecular study we here synonymize the 21 subspecies introduced by Welch (1938) and four additional taxa of other authors that Welch retained as subspecies in his monograph. Although we analyzed only a subset of the taxa listed below, as a result of population extinction, range reduction, and a lack of agreement between the trinominal taxonomy and molecular patterns, we synonymize all 25 subspecies with the nominotypical Achatinella mustelina Mighels, 1845 (p. 21), in the subgenus Achatinella Swainson, 1828 (p. 83).

Thus we synonymize with Achatinella mustelina Mighels, 1845 the following 13 taxa that were covered by the populations sampled for the molecular analyses: Achatinella muste- 


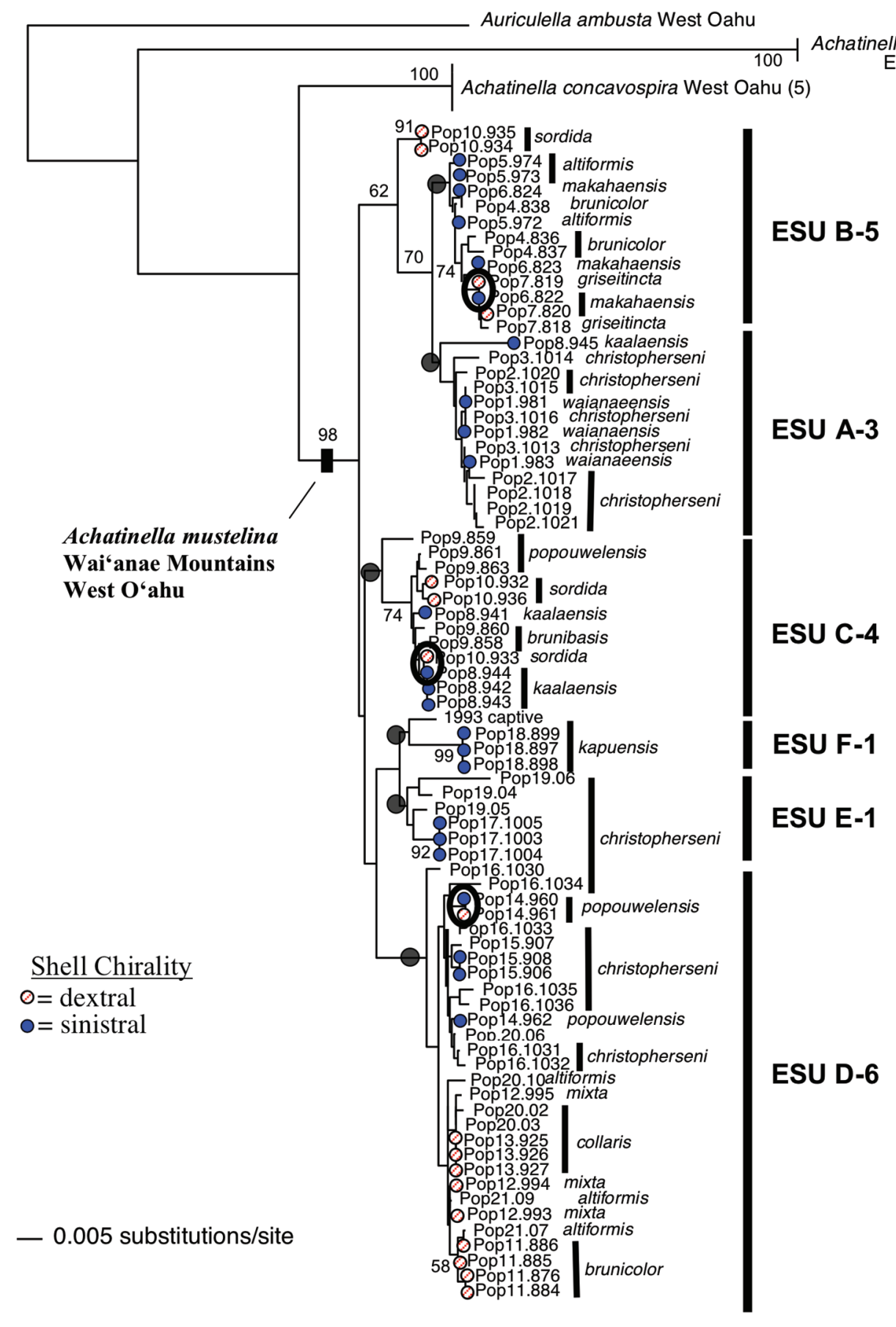

Figure 3. Mitochondrial DNA phylogeny, focusing on Achatinella mustelina, rooted using achatinellid outgroup Auricullela ambusta, and three endangered species of Achatinella and showing d'Alte Welch's (1938) subspecies names for the ingroup. Evolutionarily significant units (ESUs) as defined by Holland and Hadfield (2002) are depicted using black vertical bars labeled A-F, with number following ESU designation representing the number of trinominals making up each ESU. Solid or open circles at branch termini represent shell chirality where known. Three instances where COI haplotypes were shared between snails with opposite chirality are highlighted by black ovals. 
TABLE 1

Summary of Nucleotide and Haplotype Diversity Statistics and Gene Flow Estimates

\begin{tabular}{|c|c|c|c|c|c|c|c|}
\hline Parameter & $G_{\mathrm{ST}}$ & $F_{\mathrm{ST}}$ & $\pi$ & $H_{\mathrm{d}}$ & $N_{\mathrm{m}}$ & $D_{x y}$ & $D_{\mathrm{a}}$ \\
\hline \multicolumn{8}{|l|}{ ESU } \\
\hline Within & 0.045 & & 0.00856 & & & & \\
\hline Among & & 0.65 & & 0.91 & 4.36 & 0.032 & 0.024 \\
\hline \multicolumn{8}{|l|}{ Subspecies } \\
\hline Within & 0.1332 & & 0.00766 & & & & \\
\hline Among & & 0.25 & & 0.82 & 1.63 & 0.028 & 0.021 \\
\hline \multicolumn{8}{|l|}{ Chirality } \\
\hline Dextral vs. sinistral & 0.0095 & & 0.0289 & 0.9833 & 26.12 & 0.0299 & 0.00481 \\
\hline
\end{tabular}

Note: Values were calculated using DNAsp (Rozas et al. 2003).

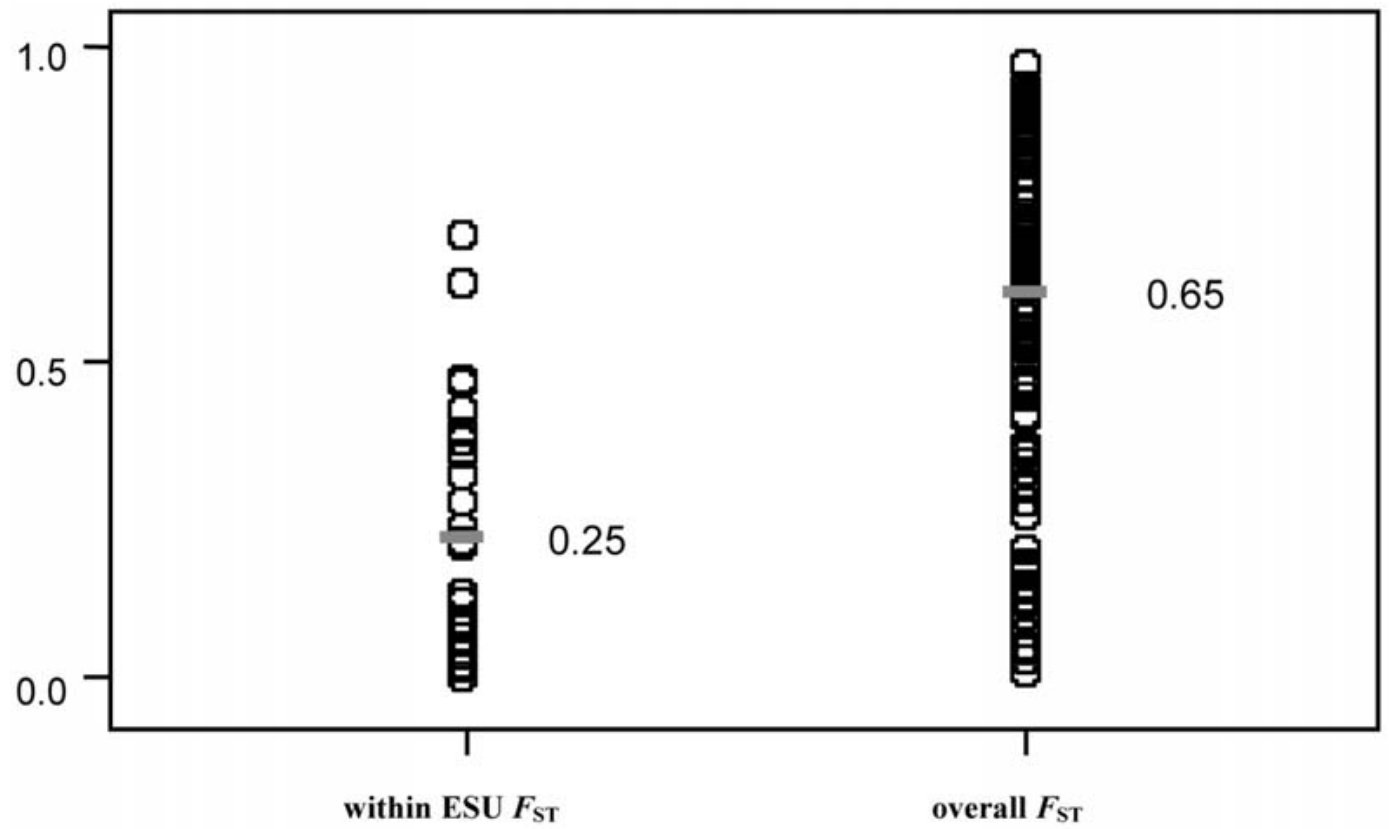

FIgURE 4. Dot plots of pairwise $F$-statistics (Wright 1978) for Achatinella mustelina, showing within-ESU and overall $F_{\mathrm{ST}}$ values with means indicated by dashes. The mean among-ESU $F_{\mathrm{ST}}$ value is significantly higher than the mean pairwise fixation index, indicating that gene flow is substantially higher within ESUs than among randomly selected populations.

lina altiformis Welch, 1938 (p. 63), Achatinella mustelina brunibasis Welch, 1938 (p. 82), Achatinella mustelina brunicolor Welch, 1938 (p. 67), Achatinella mustelina christopherseni Welch, 1938 (p. 111), Achatinella mustelina collaris Welch, 1938 (p. 91), Achatinella mustelina griseitincta Welch, 1938 (p. 78), Achatinella mustelina kaalaensis Welch, 1938 (p. 87),
Achatinella mustelina kapuensis Welch, 1938 (p. 132), Achatinella mustelina makabaensis Pilsbry \& Cooke, 1914 (in 1912-1914) (p. 345), Achatinella mustelina mixta Welch, 1938 (p. 74), Achatinella mustelina popouwelensis Welch, 1938 (p. 99), Achatinella mustelina waianaeensis Welch, 1938 (p. 43), Achatinella sordida Newcomb, 1854 (p. 13). 
We also synonymize with Achatinella mustelina Mighels, 1845 the following 12 taxa that were not sampled for molecular analysis: Achatinella lymaniana Baldwin, 1895 (p. 219), Achatinella mustelina bicolor Pfeiffer, 1859 (p. 529), Achatinella mustelina dautzenbergi Welch, 1938 (p. 140), Achatinella mustelina decolor Welch, 1938 (p. 29), Achatinella mustelina diffusa Welch, 1938 (p. 86), Achatinella mustelina griseipicta Welch, 1938 (p. 20), Achatinella mustelina lathropae Welch, 1938 (p. 103), Achatinella mustelina mailiensis Welch, 1938 (p. 42), Achatinella mustelina maxima Welch, 1938 (p. 54), Acbatinella mustelina nocturna Welch, 1938 (p. 71), Achatinella mustelina obesiformis Welch, 1938 (p. 77), Achatinella mustelina russi Welch, 1938 (p. 123).

\section{DISCUSSION}

\section{Tree Snail Chirality}

Welch (1938:144) noted that "No order can be determined in the direction of dextral and sinistral forms. The turn of the shells appears to be a random affair which can occur in any locality. Usually every prevailing dextral form has a sinistral form also." Although tall-spired cross-fertilizing hermaphroditic land snails can mate interchirally to some degree (Johnson et al. 1990, Asami et al. 1998), the idea persists that pulmonates of opposite chirality may have difficulty mating and therefore experience some degree of reproductive isolation (Ueshima and Asami 2003), which has been proposed as a sympatric speciation mechanism (Gittenberger 1988). Our data provide some support for the ability of dextral and sinistral individuals of this tall-spired species, A. mustelina, to reproduce, as evidenced by identical haplotypes shared between sinistral and dextral snails. In terms of gene-flow estimates among groups, the values between chirality groups were far higher than among ESUs or among subspecies. $G_{\mathrm{ST}}$ and $F_{\mathrm{ST}}$ showed no evidence of reduced gene flow between snails differing in chirality (Table 1). Although this evidence is strong and consistent, it is also indirect. It would be useful to conduct breeding experiments to di- rectly compare reproductive success between snails of the same versus opposite chiralities and to determine whether self-fertilization is feasible in this species [as demonstrated in the related Partulina redfieldi (Kobayashi and Hadfield 1996)] and, if so, what role this reproductive strategy plays in occurrence of different chiralities.

\section{Achatinella mustelina Nomenclature: Revision} of the Subspecies

The Hawaiian tree snails serve as an excellent model for situations where morphological plasticity and substitution rates of neutral DNA markers have a complex relationship and are often found to be largely uncoupled (Holland et al. 2004). In certain cases morphological evolution outpaces the rate of accumulation of substitutions in neutral markers. For species that are under anthropogenic extinction pressure, it may be prudent to rapidly assess the distribution of biological diversity by the most accurate means at hand. In the case of $A$. mustelina, we have shown that the use of the available infraspecific nomenclature is unfounded, because it does not accurately reflect evolutionary history or ongoing evolutionary processes. Although there has been some recent controversy regarding the utility and accuracy of mtDNA markers in defining taxonomic boundaries (Shaw 2002, Ballard and Whitlock 2004), there is broad scientific consensus that in the vast majority of situations mtDNA sequence variation reflects important aspects of evolutionary history (Funk and Omland 2003, Rubinoff and Holland 2005). The distinct phylogeographic patterns among groups of populations of $A$. mustelina revealed by Holland and Hadfield (2002) are incongruent with the distributions of the subspecies of Welch (1938).

\section{Conservation and Phylogeography}

The taxonomic entities that can be listed under the Endangered Species Act (ESA) include a genus, species, subspecies, or a "distinct population segment," with the latter being interpreted as "a group of organisms that 
represent a segment of biological diversity that shares an evolutionary lineage and contains potential for a unique evolutionary future" (National Research Council 1995:4). An example in which a phylogeographic approach has enlightened the conservation process is the Dusky Seaside Sparrow (Avise and Nelson 1989). In that case a previously unrecognized genetic split was revealed based on mtDNA analysis of nine conventionally recognized subspecies. The traditional taxonomy for this species complex, upon which ESA status and management efforts were based, had apparently failed to capture the true phylogenetic partitions within this group. Thus although no study can prove the null hypothesis that genetic differences between putative taxa are absent, we find no molecular evidence for any of the 13 subspecific boundaries tested.

\section{Conservation and Taxonomy}

As a consequence of recent catastrophic extinction rates, there is an increasing sense of urgency to our need for a better understanding of the systematics and evolutionary history of the achatinelline tree snails (Holland and Hadfield 2004). Because effective legislative and management decisions pertaining to wildlife protection require accurate identification of biological entities (e.g., O'Brien 1994, Soltis and Gitzendanner 1999, Avise 2004, Holland and Hadfield 2004), taxonomic issues such as those addressed in the study reported here have important conservation ramifications. For example, if genetic patterns had been found to be in accord with Welch's subspecies, then the maps and taxa of Welch (1938) would be relevant and useful in terms of current conservation efforts. However, because this is not the case, neither the taxa nor the maps are of conservation relevance, other than in terms of the historical distribution of A. mustelina sensu lato and preservation of shell color and pattern diversity. The field of conservation biology is plagued by difficult choices regarding which taxa can be saved and how best to allocate limited financial resources among competing conservation needs. Conservation and management deci- sions must therefore be made using the best, most up-to-date taxonomic information available (Avise 2004).

\section{ACKNOWLEDGMENTS}

We are particularly grateful to Vince Costello of the U.S. Army Garrison, Schofield Barracks, and Joel Lau of the Hawai'i Natural Heritage Program for expert field assistance in the Wai'anae Mountains. We also thank James Kellner and Peter Bjorn Erickson for laboratory assistance and sampling live specimens in the tree snail captive rearing facility at the University of Hawai'i, Mānoa. Comments and suggestions by Robert Cowie and Angus Davison substantially improved the manuscript. Endangered land snail specimens were sampled under Endangered Species Permit PRT-826600, issued by the U.S. Fish and Wildlife Service. B.S.H. was supported by NSF DEB-0316308 during the preparation of the manuscript.

\section{Literature Cited}

Asami, T., R. H. Cowie, and K. Ohbayashi. 1998. Evolution of mirror images by sexually asymmetric mating behavior in hermaphroditic snails. Am. Nat. 152:225-236.

Avise, J. C. 2004. Molecular markers, natural history, and evolution. Sinauer Associates, Sunderland, Massachusetts.

Avise, J. C., and W. S. Nelson. 1989. Molecular genetic relationships of the extinct Dusky Seaside Sparrow. Science (Washington, D.C.) 243:646-648.

Baldwin, D. D. 1893. Catalogue, land and fresh water shells of the Hawaiian Islands. Press Publ. Co., Honolulu.

. 1895. Descriptions of new species of Achatinellidae from the Hawaiian Islands. Proc. Acad. Nat. Sci. Phila. 1895:214236, pls. 10-11.

Ballard, J. W., and M. C. Whitlock. 2004. The incomplete history of mitochondria. Mol. Ecol. 13:729-744.

Carson, H. L., and K. Y. Kaneshiro. 1976. Drosophila of Hawaii: Systematics and ecological genetics. Annu. Rev. Ecol. Syst. 7:311-345. 
Cowie, R. H. 2001. Invertebrate invasions on Pacific islands and the replacement of unique native faunas: A synthesis of the land and freshwater snails. Biol. Invas. 3:119-136.

Cowie, R. H., N. L. Evenhuis, and C. C. Christensen. 1995. Catalog of the native land and freshwater molluscs of the Hawaiian Islands. Backhuys Publishers, Leiden, the Netherlands.

Crampton, H. E. 1917. Studies on the variation, distribution and evolution of the genus Partula: The species inhabiting Tahiti. Carnegie Inst. Washington Publ. 228.

Davison, A., S. Chiba, N. H. Barton, and B. Clarke. 2005. Speciation and gene flow between snails of opposite chirality. PLoS Biol. 3:1559-1571.

Felsenstein, J. 1985. Confidence limits on phylogenies: An approach using the bootstrap. Evolution 39:783-791.

Folmer, O., M. Black, W. Hoeh, R. Lutz, and R. Vrijenhoek. 1994. DNA primers for amplification of mitochondrial cytochrome $c$ oxidase subunit I from diverse metazoan invertebrates. Mol. Mar. Biol. Biotechnol. 3:294-299.

Fu, Y. X., and W. H. Li. 1993. Statistical tests of neutrality of mutations. Genetics 133:693-709.

Funk, D. J., and K. E. Omland. 2003. Species level paraphyly and polyphyly: Frequency, causes, and consequences, with insights from animal mitochondrial DNA. Annu. Rev. Ecol. Evol. Syst. 34:397-423.

Gillespie, R. G., and G. K. Roderick. 2002. Arthropods on islands: Colonization, speciation, and conservation. Annu. Rev. Entomol. 47:595-632.

Gittenberger, E. 1988. Sympatric speciation in snails: A largely neglected model. Evolution 42:826-828.

Gulick, J. T. 1905. Evolution, racial and habitudinal. Carnegie Inst. Washington Publ. 25:1-269.

Hadfield, M. 1986. Extinction in Hawaiian achatinelline snails. Malacologia 27:67-81.

Hadfield, M. G., S. E. Miller, and A. H. Carwile. 1993. Decimation of endemic Hawaiian tree snails by alien predators. Am. Zool. 33:610-622.
Hey, J., and J. Wakeley. 1997. A coalescent estimator of the population recombination rate. Genetics 145:833-846.

Holland, B. S., M. N. Dawson, G. L. Crow, and D. K. Hofmann. 2004. Global phylogeography of Cassiopea (Scyphozoa: Rhizostomeae): Molecular evidence for cryptic species and multiple invasions of the Hawaiian Islands. Mar. Biol. (Berl.) 145:1119-1128.

Holland, B. S., and M. G. Hadfield. 2002. Islands within an island: Phylogeography and conservation genetics of the endangered Hawaiian tree snail Achatinella mustelina. Mol. Ecol. 11:365-375.

- 2004. Origin and diversification of the endemic Hawaiian tree snails (Achatinellidae: Achatinellinae) based on molecular evidence. Mol. Phylogenet. Evol. 32:588-600.

Hudson, R. R., M. Slatkin, and W. P. Maddison. 1992. Estimation of levels of gene flow from DNA sequence data. Genetics 132:583-589.

Johnson, M. S., B. Clarke, and J. Murray. 1990. The coil polymorphism in Partula suturalis does not favor sympatric speciation. Evolution 44:459-464.

Jordan, S., C. Simon, and D. Polhemus. 2003. Molecular systematics and adaptive radiation of Hawaii's endemic damselfly genus Megalagrion (Odonata: Coenagrionidae). Syst. Biol. 52:89-109.

Kobayashi, S. R., and M. G. Hadfield. 1996. An experimental study of growth and reproduction in the Hawaiian tree snails Achatinella mustelina and Partulina redfieldi (Achatinellinae). Pac. Sci. 50:339-354.

Mighels, J. W. 1845. Descriptions of shells from the Sandwich Islands, and other localities. Proc. Boston Soc. Nat. Hist. 2:18-25.

National Research Council. 1995. Science and the Endangered Species Act. National Academy Press, Washington, D.C.

Nei, M. 1982. Evolution of human races at the gene level. Pages 167-181 in B. Bonne-Tamir, T. Cohen, and R. M. Goodman, eds. Human genetics, part A: The unfolding genome. Alan R. Liss, New York. 
O'Brien, S. J. 1994. A role for molecular genetics in biological conservation. Proc. Natl. Acad. Sci. U.S.A. 81:5748-5755.

Parsons, Y. M., and K. L. Shaw. 2001. Species boundaries and genetic diversity among Hawaiian crickets of the genus Laupala identified using amplified fragment length polymorphism. Mol. Ecol. 10:1765-1775.

Pfeiffer, L. 1859. Monographia heliceorum viventium. Sistens descriptiones systematicas et criticas omnium huius familiae generum et specierum hodie cognitarum. Volumen quartum. Supplementum secundum. Sistens enumerationem auctam omnium huius familiae generum et specierum hodie cognitarum, accedentibus descriptionibus novarum specierum. F. A. Brockhaus, Lipsiae [Leipzig].

Pilsbry, H. A., and C. M. Cooke Jr. 19121914. Manual of conchology. Structural and systematic. With illustrations of the species. Second series: Pulmonata. Vol. XXII. Achatinellidae. Academy of Natural Sciences, Philadelphia.

Posada, D., and K. A. Crandall. 1998. Modeltest: Testing the model of DNA substitution. Bioinformatics 14:817-818.

Price, J. P., and D. A. Clague. 2002. How old is the Hawaiian biota? Geology and phylogeny suggest recent divergence. Proc. R. Soc. Lond. B Biol. Sci. 269: 2429-2435.

Rozas, J., J. C. Sánchez-Del Barrio, X. Messeguer, and R. Rozas. 2003. DnaSP, DNA polymorphism analyses by the coalescent and other methods. Bioinformatics 19:2496-2497.

Rubinoff, D., and B. S. Holland. 2005. Between the two extremes: Mitochondrial DNA is neither the panacea nor the nemesis of phylogenetic and systematic inference. Syst. Biol. 54:952-960.

Rundell, R. J., B. S. Holland, and R. H. Cowie. 2004. Molecular phylogeny and biogeography of endemic Hawaiian succineid land snails (Pulmonata: Gastropoda). Mol. Phylogenet. Evol. 31:246-255.

Shaw, K. L. 2002. Conflict between nuclear and mitochondrial DNA phylogenies of a recent species radiation: What mtDNA reveals and conceals about modes of speciation in Hawaiian crickets. Proc. Natl. Acad. Sci. U.S.A. 99:16122-16127.

Simon, C. 1987. Hawaiian evolutionary biology: An introduction. Trends Ecol. Evol. 2:175-78.

Solem, A. 1990. How many Hawaiian land snail species are left? and what we can do for them. Bishop Mus. Occas. Pap. 30:2749.

Soltis, P. S., and M. A. Gitzendanner. 1999. Molecular systematics and the conservation of rare species. Conserv. Biol. 13:471-483.

Swofford, D. L. 2002. PAUP* Phylogenetic analysis using parsimony (*and other methods). Version 4.0b10. Sinauer Associates, Sunderland, Massachusetts.

Sykes, E. R. 1900. Mollusca. Pages 271-412, pl. 11-12 in D. Sharp, ed. Fauna Hawaiiensis Vol. 2. Cambridge University Press, Cambridge.

Thacker, R. W., and M. G. Hadfield. 2000. Mitochondrial phylogeny of extant $\mathrm{Ha}-$ waiian tree snails. Mol. Phylogenet. Evol. 16:263-270.

Ueshima, R., and T. Asami. 2003. Singlegene speciation by left-right reversal: A land-snail species of polyphyletic origin results from chirality constraints on mating. Nature (Lond.) 425:679-679.

U.S. Fish and Wildlife Service. 1981. Endangered and threatened wildlife and plants; listing the Hawaiian (O'ahu) tree snails of the genus Achatinella as Endangered species. Fed. Regis. 46:3178-3182.

- 1993. Recovery plan. O‘ahu tree snails of the genus Achatinella. U.S. Department of the Interior, U.S. Fish and Wildlife Service, Portland, Oregon.

Wagner, W. L., and V. A. Funk, eds. 1995. Hawaiian biogeography: Evolution on a hot spot archipelago. Smithsonian Institution Press, Washington, D.C.

Welch, d'A. A. 1938. Distribution and variation of the Hawaiian tree snail Achatinella mustelina Mighels in the Waianae Mountains, Oahu. Bernice P. Bishop Mus. Bull. 152.

. 1942. Distribution and variation of the Hawaiian tree snail Achatinella apex- 
fulva Dixon in the Koolau Range, Oahu. Smithson. Misc. Collect. 103. . 1954. Distribution and variation of the Hawaiian tree snail Achatinella bulimoides Swainson on the leeward and northern slopes of the Koolau Range, Oahu. Proc. Acad. Nat. Sci. Phila. 106:63-107, pls. 1-2.

1958. Distribution and variation of the Hawaiian tree snail Achatinella bulimoides on the windward slopes of the Koo- lau Range, Oahu. Proc. Acad. Nat. Sci. Phila. 110:123-211, pls. 10-14.

Wright, S. 1978. Evolution and the genetics of populations. A treatise in four volumes. Vol. 4. Variability within and among natural populations. University of Chicago Press, Chicago.

Zimmerman, E. C. 1979. Adaptive radiation in Hawaii with special reference to insects. Biotropica 2 (1): 32-38. 